\title{
ECO-INNOVATIONS AS A FACTOR OF SUSTAINABLE DEVELOPMENT OF AGRICULTURE AND FOOD PROCESSING
}

\author{
LESZEK WOŹNIAK \\ GRZEGORZ WOŹNIAK
}

\begin{abstract}
Implementing the concept of sustainable development of the food economy requires profound and rapid changes in this area of economic activity. Following the current path may intensify the already existing problem of the declining biological and health quality of food.

The aim of the paper is to define the essence and specificity of eco-innovations as a factor of sustainable development of agriculture and food processing. Bibliometric analysis based on a review of literature and an analysis of its content showed a systematic increase in the interest of scientists in the theory and practice of eco-innovations. They will be of particular importance in the evolution of food production and processing towards methods guaranteeing the highest biological and health quality of food products.

The following conclusions can be drawn: the European food economy needs a paradigm shift, i.e. it is necessary to restore and use agricultural and processing methods which will allow the return to a high content of nutrients in food. This need stems both from the very low biological and health quality of many products and also from a need to protect the agricultural environment in an effective manner. A basic instrument fostering positive evolution is the use of eco-innovations, including solutions known as traditiovations; the objectives of the European Green Deal will strongly favor the support of eco-innovations in food production and processing.
\end{abstract}

Keywords: eco-innovation management, food economy, traditiovations.

JEL codes: O32, O35, Q13.

Leszek Woźniak, MEng, PhD, DSc, ProfTit, Rzeszow University of Technology, Department of Enterprise, Management and Ecoinnovation; al. Powstanców Warszawy 8/L354A, 35-959, Rzeszów, Poland (Iwozniak@prz.edu.pl). ORCID iD: 0000-0002-3331-3033.

Grzegorz Woźniak, Statistical Office in Reszów; ul. Jana III Sobieskiego 10, 35-959 Rzeszów, Poland (wozniak.grzegorz83@gmail.com). ORCID iD: 0000-0001-9040-7637. 


\section{Introduction}

The last decades, and especially the second half of the 20th century, have been a period of continuous and significant deterioration in the quality of food produced by industrial methods. Owing to the low share of agriculture and organic processing as well as of traditional and regional production conducted in various ways, the mass production of very low-quality food has produced many negative results. Unfortunately, agriculture and food processing (Hawken, 1996; Caparros, 2016) have increasingly been the cause of many civilization diseases, which contradicts the famous statement by Hippocrates, "Let food be thy medicine...". However, the opposite happened: food began to be more and more harmful. Observation of this situation leads to the rather unexpected and apparently contrary conclusion that this negative result has also been determined by the careless and indiscriminate use in agriculture of certain innovations, defined as something new (e.g. new generations of pesticides, the issue of neonicotinoids, glyphosate, etc.), applied without the necessary assessment of negative impacts. According to P. Hawken (1996), an insecticide applied kills only a small percentage of insects considered pests. In fact, it kills all forms of life, pollutes water and soil, and ultimately causes many diseases in humans, including tumors. Thus, progress aimed at simplifying the production cycle and obtaining greater profits favored those methods which clearly had negative effects. Today, we already know that the indiscriminate use of innovations is one of major reasons for the destruction of these forms of agriculture which were really beneficial for us. The last decades have witnessed a continuous decline in the amount of most nutrients necessary for humans in crops, resulting from the removal of nutrients along with yields and the lack of compensation, the application of nitrogen only, the lack of organic matter in the soil, soil acidification, etc. This problem is reported by the sample publications specified in Table 1.

Sample publications on the declining content of nutrients in yields

Table 1

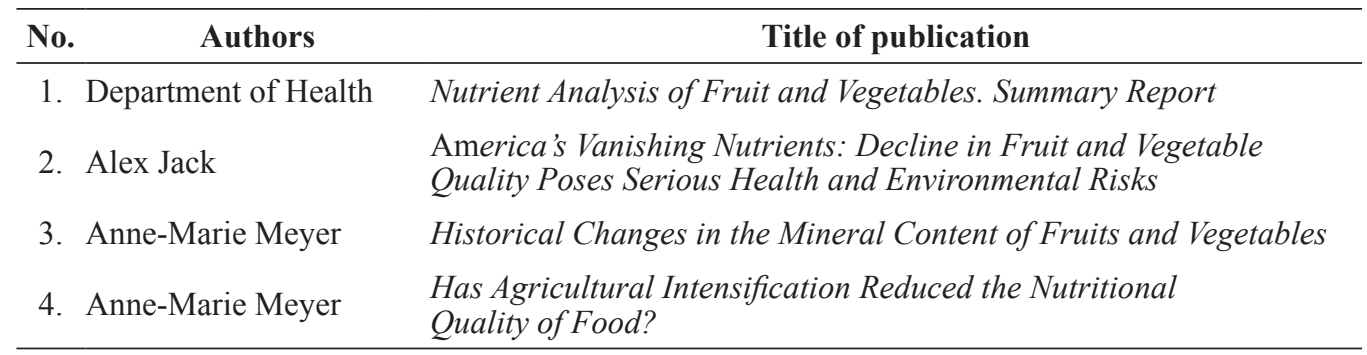

Source: own study based on: Department of Health, 2013; Jack, 2005; Mayer, 1997.

Even the renewed EU journal, in defining the concept of innovations, repeats the error of considering innovations as only new things, at least partially (OECD Eurostat, 2018). The criterion of novelty is decisive, regardless of the scope and result of the impact of this innovation on society and the environment. However, in order to remedy the situation, the basic selection criterion should be the better 
quality of a new solution; in the case of food, it should be the positive impact of an innovation on the biological and health quality of a product or the selection of such a technology or process that will allow this to be achieved without compromising the quality and leading to environmental destruction. It is this logic that is lacking in the current definition of innovations. In noticing these problems, we cannot fail to point out the existing alternative - these are environment - and communityoriented eco-innovation solutions.

\section{Materials and methods}

The basic research method used in preparing this publication was the bibliometric analysis method, which applied to the number of publications relating to the term "eco-innovation". The results of the same analysis have already been presented in the publication by S. Dziedzic (2018). This analysis used the Scopus scientific database which contains English-language publications only. However, it should be stressed that the search for publications written in Polish (on other websites) allowed the authors to find nearly two hundred titles. Scientific papers were selected taking into account the presence of the word eco-innovation $(s)$ in the title of an article, its summary, and keywords.

Bibliometric analysis was then developed by conducting a content analysis. The authors have also taken an interest in the few, so far, publications on traditiovations and in the theory of the wisdom-based economy.

Another scientific method used over the long period of analysis of this issue was observation related to the participation of one of the authors in the work and meetings of a team of scientists and practitioners involved in the creation of a multinational group, whose aim is to determine a new direction for the evolution of the food economy. The first of the authors took an active part in: "Towards Pesticide-Free Agriculture" workshop in Paris, France, 2020; "Towards PesticideFree Agriculture" workshop in Helsinki, Finland, 2019; "Towards Pesticide-Free Agriculture" workshop in Berlin, Germany, 2019; Crop Protection and Studies on the Future of Agriculture at the global scale, international conferences online, 2020. This action, entitled "Towards Chemical Pesticides-Free Agriculture", is being led by scientists from the French National Institute for Agricultural Research. The same author is one of the persons representing Poland. In the near future, we should expect the preparation of European projects, consistent with the idea of the European Green Deal, which will allow us to answer many questions about the future of the food economy in Europe.

\section{The concept and importance of eco-innovations}

The formulation of clear definitions of eco-innovations started at the end of the $20^{\text {th }}$ century. However, the European Economic and Social Committee, which assessed the provisions of the Eco-Innovation Action Plan (Eco-AP), indicated some difficulties related to establishing a universal, commonly accepted definition of eco-innovations (European Economic..., 2012). However, the example definitions in Table 2 also present the official definitions (European Commission, 
OECD) used for statistical purposes and monitoring of eco-innovations. Just like in the case of all innovations, here we can also distinguish incremental and radical eco-innovations. However, it should be stressed that they all serve to solve environmental problems.

Table 2

Selected definitions of eco-innovations

\begin{tabular}{ll}
\hline \multicolumn{1}{c}{ Authors } & \multicolumn{1}{c}{ Definition of eco-innovations } \\
\hline $\begin{array}{l}\text { C. Fussler } \\
\text { and P. James } \\
(1996)\end{array}$ & $\begin{array}{l}\text { "Eco-innovation is a process of developing new products, processes, } \\
\text { and services which provide customer and business value, but significantly } \\
\text { decrease environmental impacts". }\end{array}$ \\
& $\begin{array}{l}\text { "Eco-innovation can be defined as intentional conduct characterized by initiative, } \\
\text { comprising the stage of product design and integrated management during its }\end{array}$ \\
$\begin{array}{l}\text { M. Carley } \\
\text { life cycle, which subsequently contributes to pro-ecological modernization }\end{array}$ \\
$\begin{array}{l}\text { P. Spapens } \\
\text { (2000) }\end{array}$ & $\begin{array}{l}\text { in the indevelopment of products and related processes. Eco-innovations lead } \\
\text { to integrated solutions aimed at reducing the expenditure of resources and energy, }\end{array}$ \\
& while simultaneously improving the quality of products and services".
\end{tabular}

European "Eco-innovation is any innovation resulting in significant progress towards Commission the goal of sustainable development, by reducing the impacts of our production (2007) modes on the environment or achieving a more efficient and responsible use of natural resources, including energy".

"Eco-innovation is generally the same as other types of innovation but with two important distinctions: 1) eco-innovation represents innovation that results in

OECD a reduction of environmental impact, no matter whether that effect is intended or not;

(2009) 2) the scope of eco-innovation may go beyond the conventional organisational boundaries of the innovating organisation and involve broader social arrangements that trigger changes in existing socio-cultural norms and institutional structures".

European "Eco-innovation is any innovation that makes progress towards the goal of Commission sustainable development by reducing impacts on the environment, increasing (2011) resilience to environmental pressures or using natural resources more efficiently and responsibly".

"Eco-innovation is an area of business and technology in which modern products, production processes, services, and managerial and promotional methods are J. Przychodzeń invented and implemented, with the aim of reducing environmental risk, pollution, (2013) or any other negative environmental impact, as well as of increasing profit and improving the competitiveness of a company, and the benefits of eco-innovations should be reaped by all actors of economic life".

G. Węgrzyn (2013)

"Eco-innovation is thus a specific combination of innovation (novelty, creativity, change) with environmental sensitivity or ecological awareness".

Source: own study based on: Fussler and James, 1996; Carley and Spapens, 2000, p. 157; Klemmer, Lehr and Löbbe, 1999; EC, 2007; Sustainable Manufacturing, 2009, p. 13; EC, 2011, p. 3; Przychodzeń, 2013, p. 137; Węgrzyn, 2013. 
It can therefore be concluded that eco-innovations are new or significantly improved solutions (products, processes, methods of organization and marketing) whose objective is to manage natural resources in a different way than has so far been done, in accordance with the principles of sustainable development (innovations of sustainable development). The most important features of eco-innovations are: minimizing the use of resources, including energy; decreasing (reducing), and sometimes even eliminating, the environmental impact (burden); preventing the anthropogenic environmental burden; eliminating the concept of waste; and improving the quality and structure of industrial metabolism. By meeting these principles and objectives, eco-innovations have a comprehensive context, from generating ideas, through the use of solutions, to the final use of a product (thinking in "cradle to cradle" categories). Eco-innovations generate profits, but their important feature is the social, cultural, and ethical context; they create environment-, community-, and health-oriented thinking and action, they necessitate the evaluation of solutions. Implementing eco-innovations results in a better quality of life for all stakeholders (Dziedzic and Woźniak, 2013).

\section{Traditional knowledge and eco-innovations in the food economy}

The whole process of the health and biological degradation of food as well as of the agricultural environment, against the background of their causes, has been illustrated in detail in the publication by E. Fottorino (1999). Although it presents the situation in France, the process was the same or similar in virtually every country of Europe. Its effect was formulated by Fottorino (1999) in the following statement: "Modern agriculture is really tragic. There, we have peasants without land, here we have land without peasants... Our times have brought destruction to the traditionally understood farmer, in the name of agrarian revolutions or technical progress. Owing to the double action of mechanics and chemistry, peasants disappear for good when the best way to strengthen themselves is to destroy their neighbors." E. Fottorino (1999) points out that nature is blamed for destruction too often. He states, however, that peasants - as the author calls farmers - can cope even with drought; however, they cannot cope with the willfulness of the state and blinded leaders for whom the disappearance of the traditional farmer usually meant progress. In politics, food was considered a weapon and an opportunity for blackmail. Just like in France, American agriculture, which is completely mechanized and more connected with the stock exchange than with the farmland environment, according to the aforementioned author, is a different, but also negative, version of perverting the peasants' souls. The farmer has become more and more lonely in their work. At the same time, due to playing with chemical substances, modern farmers have led to the contamination of flowing waters and groundwater with pesticides and nitrates. With increasing productivity, profitability is regularly declining and land is growing barren. In such situation, the author's conclusion is to state: "the greatest change awaiting us in this area is perhaps a slowdown of changes" (Fottorino, 1999). A different farmer was born: one who is, unfortunately, a synthesis of technology and egoism, computer programs, and productivity (Fottorino, 1999). 
Polish farmers, even the smallest ones, are still their own masters. In Polish agriculture, traditional, informal ways of neighborly assistance have survived, although they are clearly disappearing. Traditional agriculture is "an anthem in honor of unhurriedness". Thus, the rejection of certain categories of innovations (sometimes called anti-innovations), the use of which leads to environmental degradation, appears to be an important element of maintaining the high quality of Polish agricultural products.

Are there any alternatives? Naturally, there are. The use of environment - and health-oriented innovations solves this problem. An interesting alternative is also the currently promoted theory of traditiovations, which consists in returning to the use of traditional methods, often even those from very distant times (Cannarella and Piccioni, 2011). According to these authors, innovation may be a return to the better solutions of the past, when it turns out that misunderstood progress has had mainly negative effects.

The issues concerning the use of traditional knowledge have also been the subject of studies by other authors. Examples of titles and authors of publications in this regard are provided in Table 3.

Table 3

Sample publications containing references to traditiovations

\begin{tabular}{|c|c|c|}
\hline No. & Authors & Titles of publications \\
\hline 1 & Jacinthe Bessiere & $\begin{array}{l}\text { Local Development and Heritage Traditional Food } \\
\text { and Cuisine as Tourist Attractions in Rural Areas }\end{array}$ \\
\hline 2 & Agnieszka Borowska & $\begin{array}{l}\text { The Role of Traditional and Regional Food } \\
\text { Products in Rural Development in Poland }\end{array}$ \\
\hline 3 & $\begin{array}{l}\text { Grace M. Egeland, } \\
\text { Guylaine Charbonneau-Roberts, } \\
\text { Johnny Kuluguqtuq, Jonah Kilabuk, } \\
\text { Looee Okalik, Rula Soueida, } \\
\text { Harriet V. Kuhnlein }\end{array}$ & $\begin{array}{l}\text { Back to the Future: Using Traditional Food } \\
\text { and Knowledge to Promote a Healthy Future } \\
\text { Among Inuit }\end{array}$ \\
\hline 4 & $\begin{array}{l}\text { Luigi Rosell, Gianni Cicia, Carla Cavallo, } \\
\text { Teresa Del Giudice, Domenico Carlucci, } \\
\text { Maria Clodoveo, Bernardo De Gennaro }\end{array}$ & $\begin{array}{l}\text { Consumers, Willingness to Buy Innovative } \\
\text { Traditional Food Products: The Case } \\
\text { of Extra-Virgin Olive Oil Extracted by Ultrasound }\end{array}$ \\
\hline 5 & $\begin{array}{l}\text { Ryan K. Brook, } \\
\text { Stephane M. McLachlan }\end{array}$ & $\begin{array}{l}\text { Trends and Prospects for Local Knowledge } \\
\text { in Ecological and Conservation Research } \\
\text { and Monitoring }\end{array}$ \\
\hline
\end{tabular}

Hanna Karakuła-Juchnowicz,

$6 \begin{aligned} & \text { Hanna Pankowicz, } \\ & \text { Dariusz Juchnowicz, Patrycja Szachta, } \\ & \text { Teresa Małecka-Massalska }\end{aligned}$

Psychobiotics: New Possibilities for Treatment of Affective Disorders?

Source: own study based on: Bessiere, 1998; Borowska, 2010; Egeland et al., Back to the Future...; Rosell et al., 2018; Brook and McLachlan, 2008; Karakuła-Juchnowicz, Pankowicz, Juchnowicz, Szachta, Małecka-Massalska, 2015.

As mentioned in the introduction, the careless use and abuse of any innovations in food production and processing (without the necessary environmental, ethical, and social reflection), despite a regular increase in yields of crops and productivity, 
has led to a continuous deterioration in the biological and health quality of massproduced food. Mass production and mass trade in food (globalized, controlled by corporations) has standardized the nature of food almost all over the world. Such food, very often deprived not only of nutritive values, but also of important organoleptic characteristics - its natural taste and smell - fills the shelves of markets. It is relatively cheap, so it finds buyers without any problem. Choices made without any reflection on the part of consumers guarantee the persistence of such a model. How do corporations work? Please see the book by J. Bakan (2006).

Politics has not only supported such actions, but even necessitated them, which proves the statement that every economy is political. In seeking to externalize costs and achieve economies of scale, the corporations involved in food production and processing stopped paying attention to the biological foundations of production and processing, as well as to the necessary inclusion of ethical considerations. The paradigm of the knowledge-based economy (most often misused, deliberately) and innovation have proved destructive for consumers of such food. We can endlessly note down and analyze causes and effects. In general, they are known. It is more important to indicate an alternative.

Starting with two categories of production and processing of the highest quality food (organic food, sometimes referred to as biological food, traditional and local products), it should be stressed that they fully meet the definitions, objectives, and principles of creating eco-innovations (their selected definitions are provided in Table 3) moreover, they also meet the logic of another, new paradigm of the economy based on wisdom. Its objectives were presented by A. Kukliński (2011). The basic ones are: imagination, allowing us to perceive the long-term strategic consequences of decisions made; integration of knowledge, imagination, and experience; and an absolutely basic awareness of a standard of good and evil. The introduction of ethics as a basis for measures taken is of fundamental importance (Kukliński, 2011). This type of assumption and conduct has been known for a long time in the logic of functioning of organic food production and processing. They are also a basis for thinking about eco-innovations. The objectives of creating eco-innovations have been presented by many authors. Some of them include (Weiszacker, Lovins, Lovins, Munchen, Knaur, 1995, quoted in: Carley and Spapens, 2005):

- much less waste and pollution and, if possible, their complete elimination;

- better quality of life - eco-innovations improve the quality of all benefits achieved;

- social justice and jobs - a clear reduction in the consumption of resources is accompanied by a higher share of human capital in production, which results in a lower unemployment rate;

- competitiveness - eco-innovations are new, or returning to tradition, better technologies, processes, and products;

- market attractiveness and business benefits - it has already been proved that eco-innovations are cost-effective, do not require any special legislation, and create a very good public image for business;

- profitability - various types of savings resulting from the reduced consumption of raw materials and energy are more attractive than the purchase and use of 
new resources, which are often already lacking, pollution prevention is cheaper than obsolete "end-of-pipe" measures, lower risk - reduced amounts, and even complete elimination, of certain categories of toxic waste result in improving public health, as well as the safety of workers and consumers;

- efficient use of limited development capital - this is favored by the construction of eco-innovation infrastructure;

- international security - eco-innovations allowing for limitation of the competitive struggle for shrinking resources, as well as limitation or elimination of potential international conflicts.

Eco-development companies should be closely linked with the area of the food economy. Such enterprises, according to P. Hawken (1996), are characterized by the following features:

- replace foreign goods and products produced in other parts of the country with regionally or locally produced products;

- take full responsibility for the results of their environmental impact (this is the role played by organic farming);

- can develop without an influx of capital from distant sources, which allows for the avoidance of a debt spiral;

- organize forms of production and services which are valuable, protect human dignity, and bring satisfaction to workers;

- are involved in producing durable products which may be used for a long time. Their eventual disposal or use does not bring any harm to future generations and the environment;

- are involved in educating informed consumers and thus regularly turn them into informed consumers.

New proposals related to returning to solutions of the past in food production and processing (back then, those solutions were fully ecological, respected the rights of nature, and were based on natural biological processes), so-called traditiovations, already appearing in theory, are usually also eco-innovations. Therefore, these three ideas (eco-innovations, traditiovations, wisdom), which are very closely interrelated, together give a picture of the possible, and even necessary, evolution of the food economy.

Examples of eco-innovations in the food economy include: biological methods of plant protection, new natural fertilizers, cost-effective solutions in water management, cultivation safe for preserving necessary soil properties (e.g. zero tillage).

\section{Selected results of bibliometric analysis on eco-innovations}

The bibliometric analysis was carried out taking into account the presence of the following terms in publications: eco-innovations or eco-innovation, in the title, keywords, or summary. Fig. 1 shows the number of publications relating to eco-innovation between 2000 and 2017. Since such results have already been published by another author, this source is included in the quotations below the figures. 


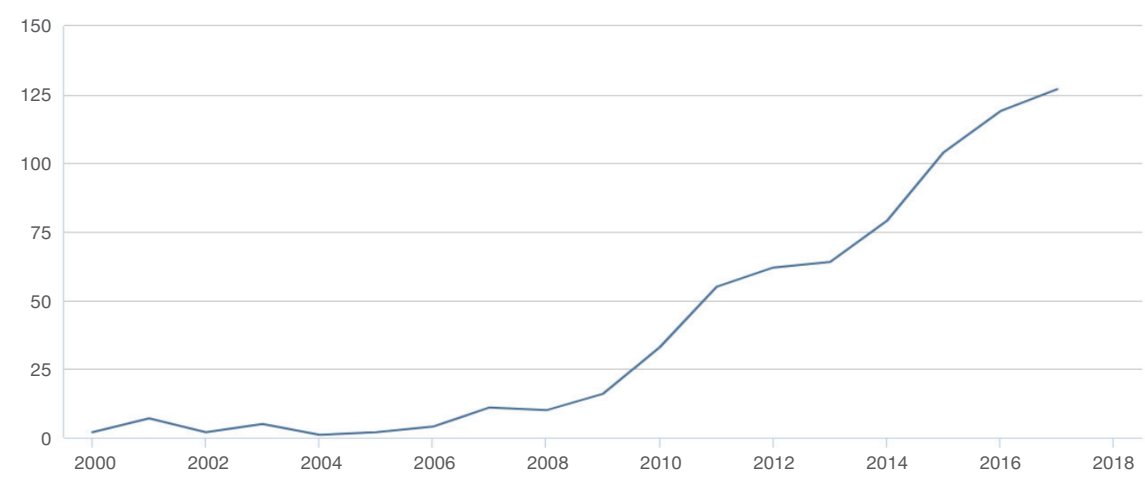

Fig. 1. Number of publications relating to eco-innovations between 2000 and 2017.

Source: Scopus - scientific database kept by the Elsevier publishing house, as of 31.12.2017. quoted in: S. Dziedzic, 2018.

As demonstrated by the data in Fig. 1, a very clear increase in the number of publications relating to eco-innovations on a global scale was found from 2000 (first publications) to 2017. The most dynamic increase can be observed after 2010.

Fig. 2 shows the number of scientific publications containing the concept of ecoinnovations in selected scientific journals.

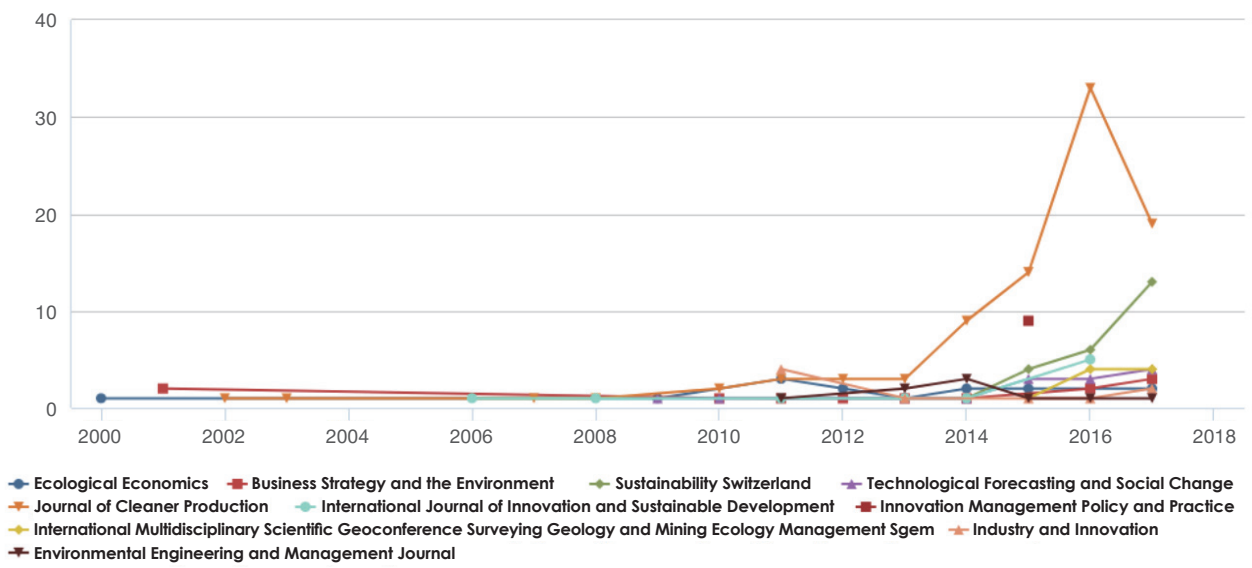

Fig. 2. Scientific publications containing the concept of eco-innovations in terms of the selection of scientific periodicals, in which the number of publications was the largest.

Source: as for Fig. 1.

The data presented in Fig. 2 show that the greatest number of publications relating to eco-innovations was published in the Journal of Cleaner Production, and a particular increase in this number was observed after 2013. The large growth rate in this type of publication was also observed in the case of the Innovation Management Policy and Practice journal.

Fig. 3 shows the countries that were leaders in the number of scientific publications containing the concept of eco-innovations in 2017. 


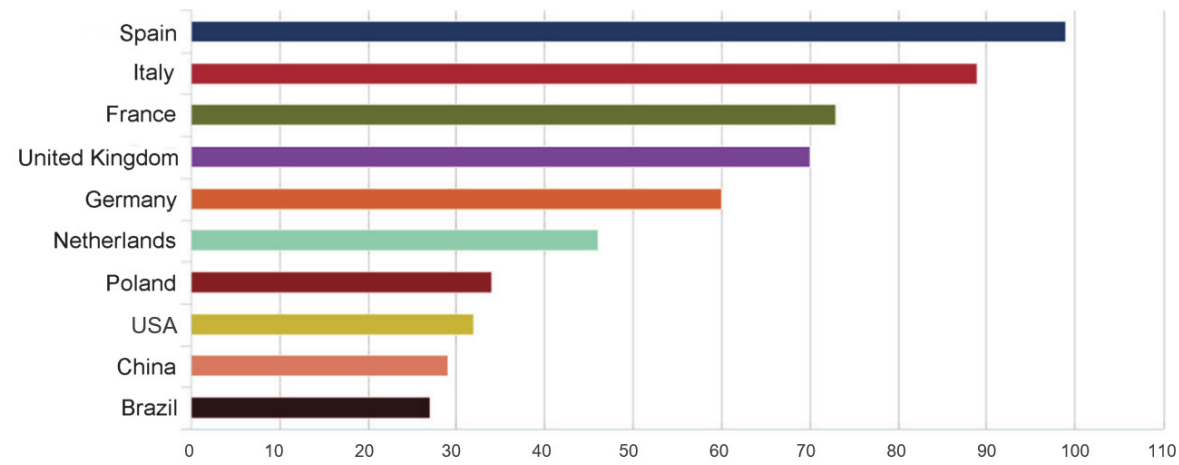

Fig. 3. Scientific publications containing the concept of eco-innovations in the individual countries of the world.

Source: as for Fig. 1.

As can be seen from the data in Fig. 3, in 2017 Poland was ranked seventh in terms of the number of scientific publications addressing the issue of eco-innovations. The leaders in this ranking were Spain and Italy, as these were the countries whose scientists published the largest number of papers related to eco-innovations.

Fig. 4 shows the ranking of EU countries in terms of eco-innovative solutions introduced in 2019.

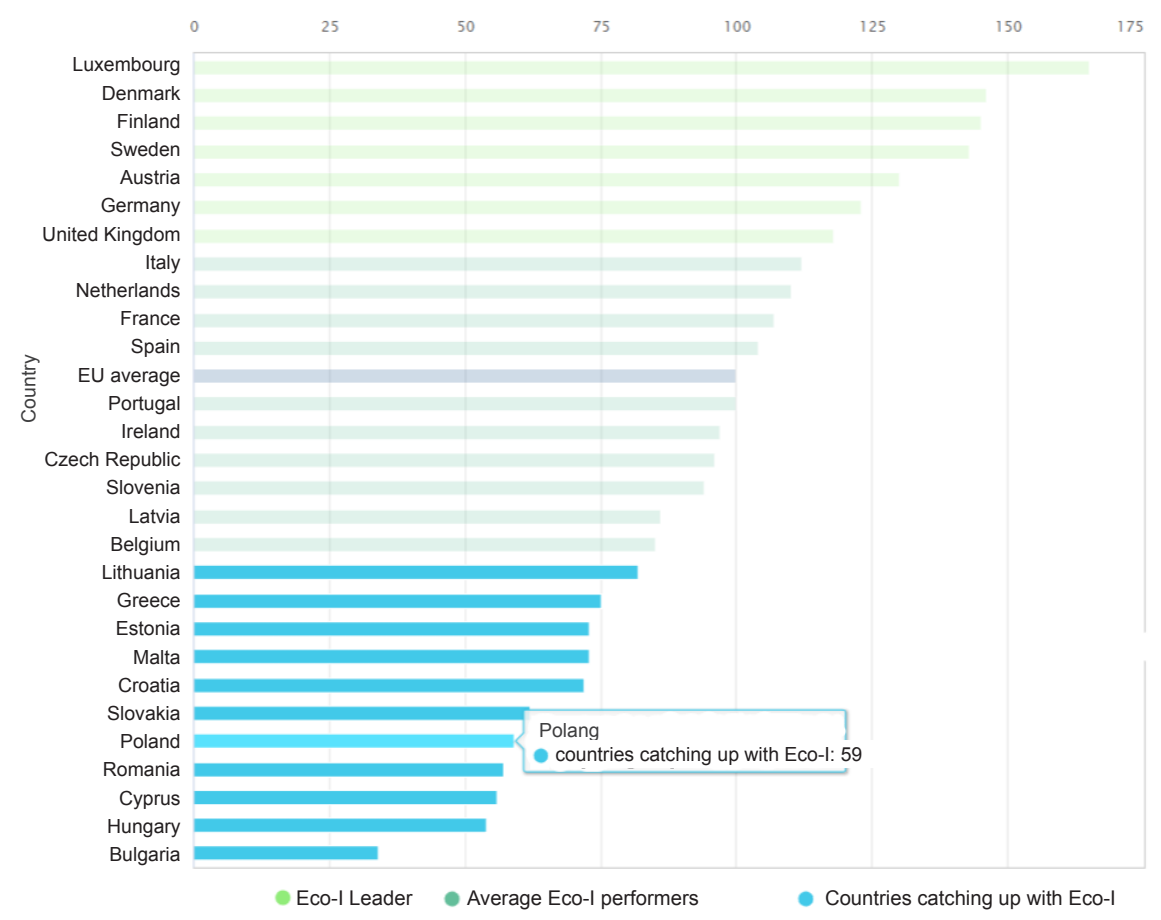

Fig. 4. Ranking of EU countries in terms of eco-innovation in 2019.

Source: https://ec.europa.eu/environment/ecoap/indicators/index_en (access date: 10.11.2020). 
Eco-innovation in the Polish economy is still far below the European average; currently we are ranked fifth from last place. Most eco-innovations are created by the economy in Luxembourg and Denmark (Fig. 4). However, it should be noted that such rankings are not able to pick out specific areas of creating eco-innovations. Eurostat does not collect data on specific industries and sectors.

Eco-innovation should be fostered by regional innovation strategies. An analysis carried out in this regard showed that the most eco-innovative strategy is the Regional Innovation Strategy of the Podkarpackie Voivodeship for 2014-2020 for Smart Specialization (Dziedzic, 2018).

An analysis carried out in 2015 (Table 4), in terms of six groups of indicators, allowed Poland to be included among the countries catching up with others in terms of eco-innovations. What should be highlighted are the social effects of eco-innovations in Poland.

The number of reasons determining the intensified search for eco-innovations is clearly growing. Among newer trends, we can highlight the EU's striving for achieving the objectives of the "European Green Deal". The permanent reasons for creating eco-innovations are as follows (Woźniak, 2010):

- ecological reasons: limited environmental capacity for waste (there is no such capacity at all for toxic waste); decreasing supply of raw materials, which are lacking and thus their price is going up; degradation of ecosystems;

- social causes: issues relating to public health; seeking to create stable and safe jobs;

- economic reasons: necessary internalization of all production and consumption costs; striving to create cheaper and more competitive solutions; the need to consider the increasingly demanding environmental law.

In the context of the statements presented, the statement of A. Kaleta (2016), according to which the identification of the market importance and value of ideas and inventions as early as possible is relevant in the case of all innovations, may be particularly significant. It is important to identify, as early as possible, economic developments in markets for raw materials, as well as new trends in consumer behavior and related consequences in the form of new social phenomena.

The issue of eco-innovations is particularly important in these areas (sectors, industries, sections of the economy) whose importance to humanity is the greatest and which today show clear signs of qualitative degradation of products. The most visible area of this kind is the food economy, where, in view of the changes that have already occurred, a policy of supporting eco-innovations, for example, by creating solutions consistent with the logic of the aforementioned traditiovations, is absolutely necessary for the purpose of enhancing the biological and health quality of products. 
Eco-innovation index in 2015 in the EU-28 countries

\begin{tabular}{|c|c|c|c|c|c|c|c|}
\hline & Item & 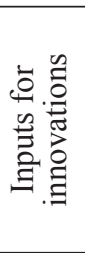 & 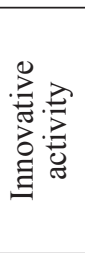 & 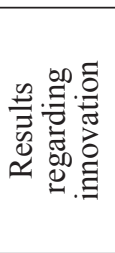 & 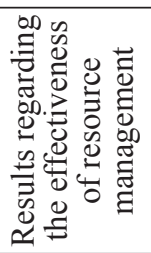 & 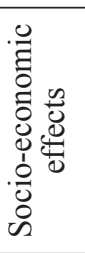 & 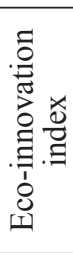 \\
\hline \multirow{7}{*}{ 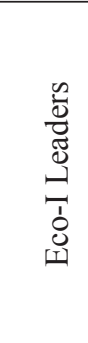 } & Denmark & 368 & 71 & 157 & 108 & 86 & 167 \\
\hline & Finland & 182 & 152 & 190 & 77 & 120 & 140 \\
\hline & Ireland & 310 & 135 & 65 & 104 & 63 & 134 \\
\hline & Germany & 154 & 162 & 140 & 107 & 87 & 129 \\
\hline & Sweden & 121 & 154 & 160 & 102 & 93 & 124 \\
\hline & Luxembourg & 106 & 115 & 205 & 131 & 60 & 124 \\
\hline & France & 111 & 110 & 108 & 108 & 138 & 115 \\
\hline \multirow{9}{*}{ 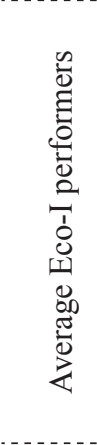 } & Austria & 98 & 126 & 136 & 107 & 73 & 108 \\
\hline & Spain & 94 & 134 & 102 & 112 & 105 & 106 \\
\hline & Italy & 75 & 118 & 117 & 116 & 101 & 106 \\
\hline & United Kingdom & 126 & 116 & 74 & 126 & 87 & 106 \\
\hline & Portugal & 79 & 167 & 83 & 86 & 99 & 102 \\
\hline & Czech Republic & 63 & 181 & 47 & 66 & 147 & 99 \\
\hline & Netherlands & 66 & 77 & 106 & 124 & 108 & 98 \\
\hline & Belgium & 89 & 116 & 111 & 98 & 71 & 97 \\
\hline & Slovenia & 74 & 92 & 98 & 78 & 142 & 96 \\
\hline \multirow{12}{*}{ 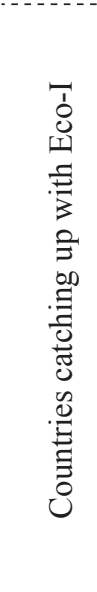 } & Romania & 39 & 138 & 53 & 64 & 120 & 82 \\
\hline & Hungary & 72 & 98 & 27 & 81 & 126 & 81 \\
\hline & Estonia & 78 & 129 & 53 & 48 & 100 & 80 \\
\hline & Latvia & 43 & 60 & 95 & 70 & 109 & 75 \\
\hline & Lithuania & 43 & 94 & 59 & 81 & 87 & 73 \\
\hline & Greece & 57 & 37 & 101 & 78 & 61 & 72 \\
\hline & Slovakia & 38 & 101 & 52 & 78 & 87 & 72 \\
\hline & Croatia & 21 & 100 & 89 & 80 & 49 & 67 \\
\hline & Malta & 25 & 72 & 55 & 104 & 46 & 64 \\
\hline & Cyprus & 14 & 54 & 132 & 77 & 17 & 60 \\
\hline & Poland & 40 & 54 & 58 & 62 & 77 & 59 \\
\hline & Bulgaria & 19 & 71 & 27 & 46 & 81 & 49 \\
\hline \multicolumn{2}{|c|}{ Minimum } & 14 & 37 & 27 & 46 & 17 & 49 \\
\hline \multicolumn{2}{|c|}{ Maximum } & 368 & 181 & 205 & 131 & 147 & 167 \\
\hline \multicolumn{2}{|c|}{ Scope } & 354 & 144 & 178 & 86 & 131 & 118 \\
\hline
\end{tabular}

Source: own study based on Policies and Practices for Eco-Innovation Uptake and Circular Economy Transition, EIO Bi-Annual Report, November 2016, European Commission, p. 37; as cited in: Dziedzic, 2018. 


\section{Conclusions}

Implementing the concept of sustainable development of the food economy requires profound and rapid changes in this area of economic activity. Following the current path would undoubtedly intensify the already existing problem of the declining biological and health quality of food. Methods that can tackle these problems are already available and recognized. Existing innovations in agriculture, which can also be blamed for the current situation, may be quickly and effectively replaced by a new category - eco-innovations, which certainly also include the solutions defined as traditiovations. It has also been stated that traditiovations, which have many positive features, also fit the logic of functioning of a new paradigm of the economy - based on wisdom. It is underpinned by ethics and imagination regarding the future. The interpretation of innovations in which the only criterion is the novelty of the proposed solution, without a detailed analysis of the consequences of its use, cannot continue to be applied to agriculture and food processing.

The solutions proposed in the "European Green Deal" also take into account the need for eco-innovations. Of fundamental importance may be traditional methods of water management (water is the essence of agriculture) and a return to the common use of microorganisms, instead of synthetic chemicals which are also harmful to humans.

These proposals are not new. The current model of organic (biological) farming takes this idea into account. It is connected with many ideas concerning traditional and local products. Adequate support for the idea of eco-innovations may significantly accelerate this process.

Bibliometric analysis showed a systematic increase in the interest of scientists in the theory and practice of eco-innovations. They will be of particular importance in the evolution of food production and processing towards methods guaranteeing the highest biological and health quality of food products. We should also mention the enormous role assigned to eco-innovations in the European objectives of the resource-efficient and low-carbon economy, as well as in the logic of the "European Green Deal". The content of publications relating to eco-innovations has pointed to their ever-growing role in stimulating the development of the food economy in the appropriate direction.

These issues have been of interest, inter alia, in solutions raised during a discussion as part of the Towards Chemical Pesticides-Free Agriculture program. Thus, observation has confirmed the fact that there is a European trend towards solving the problems related to the effects of the industrial food production method.

The more common use of eco-innovations and traditiovations will be able to guarantee the sustainable development of the food economy, pursuant to the idea of creating the foundations of the wisdom-based economy. This logic of thinking by A. Kukliński, mentioned in the text, does not contradict the objectives of the knowledge-based economy, but only gives it a more desirable, contemporary direction. 
The following conclusions may be drawn:

- the European food economy requires a paradigm shift. This need stems both from the very low biological and health quality of many products, but also from a need to protect the agricultural environment in an effective manner;

- the use of eco-innovations, including solutions known as traditiovations, is an essential instrument fostering positive evolution;

- the objectives of the European Green Deal will strongly favor the support of eco-innovations in food production and processing;

- it is necessary to restore and use agricultural and processing methods which will allow the return to a high content of nutrients in food. 


\section{References}

Bakan, J. (2006). Korporacja. Patologiczna pogoń za zyskiem i władza. Warszawa: Wydawnictwo Lepszy Świat.

Bessiere, J. (1998). Local Development and Heritage Traditional Food and Cuisine as Tourist Attractions in Raral Areas. Sociologia Ruralis, Vol. 38, No. 1.

Borowska, A. (2010). The Role of Raditional and Regional Food Products in Rural Development in Poland. Social Research, No. 1(18), pp. 40-52.

Brook, R.K., McLachlan, S.M. (2008). Trends and Prospects for Local Knowledge in Ecological and Conservation Research and Monitoring. Biodiversity and Conservation, 17, 3501-3512.

Cannarella, C., Piccioni, V. (2011).Traditiovations: Creating Innovation from the Past and Antique Techniques for Rural Areas. Technovation, 31, 689-699.

Caparros, M. (2016). Głód. Kraków: Wydawnictwo Literackie.

Carley, M., Spapens, P. (2000). Dzielenie się światem. Białystok-Warszawa: Instytut na rzecz Ekorozwoju.

Department of Health (2013). Nutrient Analysis of Fruit and Vegetables. Summary Report. Retrieved from: https:/www.gov.uk/government/publications/nutrient-analysis-of-fruit-and-ve-getables (access date: 30.11.2020).

Dziedzic, S. (2018). Ekoinnowacje w regionalnych strategiach innowacji. Istota, uwarunkowania, modelowanie. Rzeszów: Oficyna Wydawnicza Politechniki Rzeszowskiej.

Dziedzic, S., Woźniak, L. (2013). Ekoinnowacje jako priorytetowy kierunek „, Regionalnej Strategii Innowacji Województwa Podkarpackiego”. Rzeszów: Oficyna Wydawnicza Politechniki Rzeszowskiej.

Egeland, G.M., Charbonneau-Roberts, G., Kuluguqtuq, J., Kilabuk, J., Okalik, L., Soueida, R., Kuhnlein, H.V. (2009). Back to the Future: Using Traditional Food and Knowledge to Promote a Healthy Future among Inuit. In: H.V. Kuhnlein, B. Erasmus, D. Spigelski (eds.), Indigenous People's Food System: the Many Dimensions of Culture, Diversity and Environment for Nutrition and Health. Rome: FAO.

European Commission (2007). Competitiveness and Innovation Framework Programme (2007 to 2013). European Commission (2011). Komunikat Komisji do Parlamentu Europejskiego, Rady, Europejskiego Komitetu Ekonomiczno-Społecznego i Komitetu Regionów Innowacja na rzecz zrównoważonej przyszłości - Plan działania w zakresie ekoinnowacji (Eco-AP), COM(2011) 899 (final), Brussels 15.12.2011, p. 3.

European Economic and Social Committee (2012). Opinia Europejskiego Komitetu Ekonomiczno-Społecznego w sprawie komunikatu Komisji do Parlamentu Europejskiego, Rady, Europejskiego Komitetu Ekonomiczno-Społecznego i Komitetu Regionów „Innowacja na rzecz zrównoważonej przyszłości - Plan działania w zakresie ekoinnowacji (Eco-AP)" COM(2011) 899 (final), Brussels 18.09.2012.

Fottorino, E. (1999). Człowiek ziemi. Warszawa: Ludowa Spółdzielnia Wydawnicza.

Fussler, C., James, P. (1996). Eco-Innovation. A Breakthrough Discipline for Innovation and Sustainability. London: Pitman Publishing.

Hawken, P. (1996). Przez zielone okulary. Jak prowadzić interesy i nie szkodzić sobie i innym. Warszawa: Wydawnicto Pusty Obłok.

Jack, A. (2005) America's Vanishing Nutrients: Decline in Fruit and Vegetable Quality Poses Serious Health and Environmental Risks. Becket: Amberwaves.

Kaleta, A. (2016). Między tradycyjną a nowoczesną analizą strategiczną. Przegląd Organizacji, No. 3, pp. 4-8. 
Karakuła-Juchnowicz, H., Pankowicz, H., Juchnowicz, D., Szachta, P., Małecka-Massalska, T. (2015). Psychobiotics: New Possibilities for Treatment of Affective Disorders? Farmakoterapia w Psychiatrii i Neurologii, No. 31(3-4), pp. 229-242.

Klemmer, P., Lehr, U., Löbbe, K. (1999). Environmental Innovation. Incentives and Barriers. German Ministry of Research and Technology (BMBF). Berlin: Analytica-Verlag.

Kukliński, A. (2011). Od gospodarki opartej na wiedzy do gospodarki opartej na mądrości. Na spotkanie z enigmą XXI wieku. Biuletyn PTE, nr 2(52).

Mayer, A.M. (1997). Historical Changes in the Mineral Content of Fruits and Vegetables. British Food Journal, Vol. 99, No. 6, pp. 207-211. Retrieved from: https:/www.emerald.com/insight/con-tent/doi/10.1108/00070709710181540/full/html (access date: 30.11 .2020 ).

OECD (2009). Sustainable Manufacturing and Eco-Innovation. Framework, Practices and Measurement. Synthesis Report, p. 13.

OECD Eurostat (2018). Guidelines for Collecting, Reporting and Using Data on Innovation. The Measurement of Scientific, Technological and Innovation Activities. Oslo Manual 2018.

Przychodzeń, J. (2013). Cooperation as a Factor Improving Eco-Innovation of Companies. Organization and Management, No. 158, p. 137.

Rosell, L., Cicia, G., Cavallo, C., Del Giudice, T., Carlucci, D., Clodoveo, M.L., De Gennaro, B.C. (2018). Consumers' Willingness to Buy Innovative Traditional Food Products: The Case of Extra-Virgin Olive Oil Extracted by Ultrasound. Food Research International, 108, pp. 428-490.

Weiszacker, E., Lovins, A., Lovins, H., Munchen, Knaur, 1995, as cited in: M. Carley, P. Spapens, Dzielenie..., op. cit., pp. 159-160.

Węgrzyn, G. (2013). Ekoinnowacje w Polsce na tle krajów Unii Europejskiej. Ekonomia i Środowisko, nr 3(46), pp. 138-148.

Woźniak, L. (2010) . Możliwe kierunki rozwoju ekoinnowacyjności - poziom globalny, wspól-notowy i kraju. In: L. Woźniak, J. Strojny, E. Wojnicka (eds.), Ekoinnowacyjność dziś i jutro - wyzwania, bariery rozwoju oraz instrumenty wsparcia (pp. 7-24). Warszawa: PARP. 


\title{
EKOINNOWACJE JAKO CZYNNIK ROZWOJU ZRÓWNOWAŻONEGO ROLNICTWA I PRZETWÓRSTWA ŻYWNOŚCI
}

\begin{abstract}
Abstrakt
Realizacja koncepcji zrównoważonego rozwoju gospodarki żywnościowej wymaga głębokich i szybkich zmian $w$ tym obszarze działalności gospodarczej. Dalsze podążanie dotychczasową droga może pogłębić już istniejący problem coraz niższej jakości biologicznej i zdrowotnej żywności.

Celem pracy jest określenie istoty i specyfiki ekoinnowacji jako czynnika zrównoważonego rozwoju rolnictwa i przetwórstwa żywności. Analiza bibliometryczna oparta na przegladzie literatury i analizie jej treści wykazała systematyczny wzrost zainteresowania naukowców teoria i praktyka ekoinnowacji. Będa one miaty szczególne znaczenie w ewolucji produkcji i przetwórstwa żywności w kierunku metod gwarantujacych najwyższa jakość biologiczna i zdrowotna produktów żywnościowych.

$Z$ przedstawionych rozważań można wyciagnać następujace wnioski: europejska gospodarka żywnościowa wymaga zmiany paradygmatu, tj. niezbęne jest odtworzenie $i$ wykorzystanie metod rolnictwa i przetwórstwa, które pozwola powrócić do wysokiej zawartości biogenów w żywności. Potrzeba ta wynika zarówno ze stwierdzanej bardzo niskiej jakości biologicznej i zdrowotnej wielu produktów, ale także z konieczności skutecznej ochrony środowiska rolniczego; podstawowym instrumentem sprzyjającym pozytywnej ewolucji jest wykorzystanie ekoinnowacji, w tym także rozwiazań określanych mianem traditiovations; założenia Europejskiego Zielonego Ładu będa zdecydowanie sprzyjały wsparciu ekoinnowacji w produkcji i przetwórstwie żywności.
\end{abstract}

Słowa kluczowe: zarządzanie ekoinnowacjami, gospodarka żywnościowa, innowacje tradycyjne.

Accepted for print: 15.03.2021.

Unless stated otherwise all the materials on the website are available under the Creative Commons Attribution 4.0 International license.

Some rights reserved to the Institute of Agricultural and Food Economics - National Research Institute.

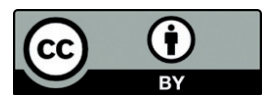

